\title{
Differences in morphology and life history traits of the echinoid Echinometra lucunter from different habitats
}

\author{
John B. Lewis ${ }^{1}$ and Gail S. Storey ${ }^{2}$ \\ ${ }^{1}$ The Redpath Museum and The Institute of Oceanography, McGill University, Montreal, Quebec H3A 2K6, Canada \\ ${ }^{2} 3010$ West Fifth Ave., Vancouver, B. C. V6K 1T9, Canada
}

\begin{abstract}
Populations of the echinoid Echinometra lucunter (Linnaeus) were sampled every month for 1 yr from a habitat subjected to heavy wave action and from a low waveenergy habitat at Barbados, West Indies. Differences in morphology and life history traits between the 2 sites were compared. Urchins from the high wave-energy habitat had thicker tests, were smaller, flatter and narrower, and differed in their pattern of ocular insertion from urchins at the low wave-energy site. Urchins from the high wave-energy habitat spawned once a year whereas those from the low waveenergy habitat spawned twice a year.
\end{abstract}

Echinometra lucunter (Linnaeus) is a common West Indian echinoid with a wide distribution in the western Atlantic Ocean between Florida and Bermuda in the north to the south-east coast of Brazil. It was first recorded in Barbados by Doderlein and Hartmeyer (1916) and later by Clark (1919, 1921). It occurs in considerable numbers around the coast of Barbados (Lewis, 1960; Lawrence and Kafri, 1979) and is most abundant on areas of rubble bottom and upon other hard rock substrata. E. lucunter is mainly a shallowwater form ( 0 to $3 \mathrm{~m}$ ) but may occur as deep as $45 \mathrm{~m}$ (Koehler, 1908).

Mayr (1954) has noted the wide morphological variation between populations of Echinometra lucunter over its geographical range. Colour is also variable, both of spines and test (Mortensen, 1943; Kier and Grant, 1965; McPherson, 1969). Differences in size, growth rates, densities and reproductive characteristics in separate populations have also been reported (McPherson, 1969; Abbott et al., 1974; Lawrence and Kafri, 1979).

The purpose of this study is to determine what intraspecific differences in morphology and life history traits exist between 2 populations of Echinometra lucunter living in widely different habitats, but separated by a distance of only $25 \mathrm{~km}$. Populations of E. Iucunter were sampled from 2 sites on the south and east coasts of Barbados. At Little Bay on the east coast the urchins live in the intertidal zone on a ledge which fronts a vertical cliff between 5 and $15 \mathrm{~m}$ in height. The site is subjected to heavy wave action (Lewis, 1960) as is the whole of the east (windward) coast (Lawrence and Kafri, 1979). The Graves End location is situated on the low wave-energy south coast of Barbados. The substratum at this site is composed of sand and coral rubble and supports a flourishing Thalassia testudinum König seagrass community. The urchins live beneath and in the crevices of the coral rubble among the seagrass.

Random samples of approximately 100 urchins were collected at monthly intervals from both habitats. Length, width and height (distance from buccal membrane to apical system) of the specimens were measured with calipers in the ambital region of the test between the spines. Each urchin was then placed in an overflow vessel filled with sea water and the live volume (with spines) was calculated from the amount of water displaced.

The 50 largest urchins from each site were retained for gonad examination. Gonad condition was estimated by microscopic examination of a gonad sample smeared on a glass slide (Moore, 1934). All urchins examined showed evidence of previous breeding. Thus a shrunken gonad was an indication that the urchin was spent and not immature. The ripe gonads of both sexes ran freely when broken and this was also used as a guide in estimating ripeness. Urchins were classified as male or female, and ripe, unripe or spent. Gonad volumes were calculated by the displacement method. A gonad index was expressed as a ratio of ten times the total gonad volume (C.V.) of each urchin to the live test volume (T.V.). This index was used in order to facilitate the comparison of gonad volumes of mature urchins of different sizes (Moore, 1934). 
The colour of the spines and test of each urchin from monthly collections was also noted. Four predominant colours were present - red, black, brown and green. Only a few urchins with intermediate colours were observed.

Between January and May 20 additional urchins were collected each month from Little Bay and from Graves End. They were put into a solution of laundry bleach (ca. $5.25 \%$ sodium hypochlorite) until the spines fell away from the test. Length, width and height of the bared test were then measured. The apical system of each test was examined to determine which ocular plates were inserted into the periproct. All ambulacral plates on the ambitus of every urchin were examined and the number of pore pairs on each plate counted. Thus, 10 arcs of pores were counted in each urchin. An interambulacral plate was selected from the ambitus of interambulacra 3 (Lovén's system; Lovén, 1874) and the thickness of this plate was measured at the suture of the interambulacral plates. This measurement was taken under a microscope with a micrometer eyepiece. The test thickness was measured to the nearest $0.1 \mathrm{~mm}$. One spine was taken from the same position on every interambulacral ambital region of each urchin (5 primary spines) and a mean spine length was calculated for each urchin.

Although Echinometra lucunter is not circular but elliptical in shape, the test length along the elliptical axis (Lovén's axis I, 3) was used as a criterion of size. In order to justify using test length as a primary parameter, the correlation coefficients of test length and test width, length and height, and length and volume were calculated. Test length was highly correlated with test width, height and live volume (correlation coefficients between 0.86 and 0.97 ) and its use as a measure of size is thus justified.

The results of size measurements are summarized in Fig. 1 in which the monthly mean urchin lengths for both areas are shown. Harding's (1949) method of resolving polymodal frequency distributions was used. In the monthly collections from Little Bay, urchins ranged in test length from 8 to $47 \mathrm{~mm}$, and monthly

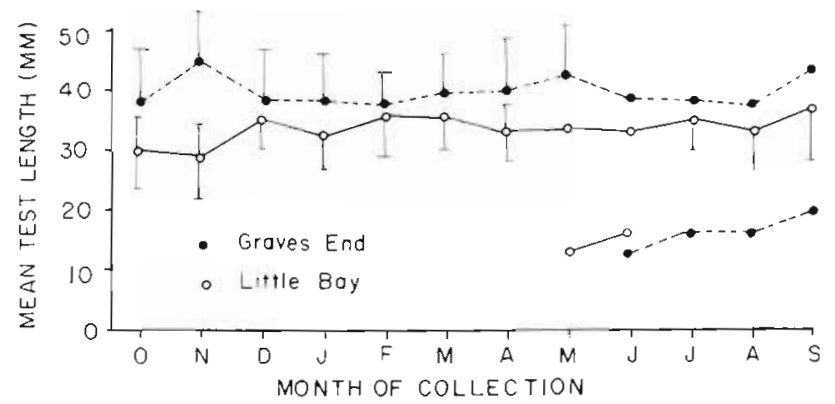

Fig. 1. Mean monthly test lengths $( \pm \mathrm{SD}$ ) of Echinometra lucunter from Little Bay and Graves End mean lengths were consistently less than the mean lengths of Graves End urchins. Urchins measuring up to $70 \mathrm{~mm}$ in length were found at Graves End with those over $47 \mathrm{~mm}$ in length comprising $15 \%$ of total collections there.

The results of analyses of seasonal changes in gonads are shown as mean gonad indices from both areas in Fig. 2, and as percentages of ripe individuals in Fig. 3. The mean monthly gonad index of urchins from Little Bay rose steadily from October until July when spawning began. The monthly gonad index of urchins from Graves End was at a peak in November, fell to a minimum value in February, and rose to a

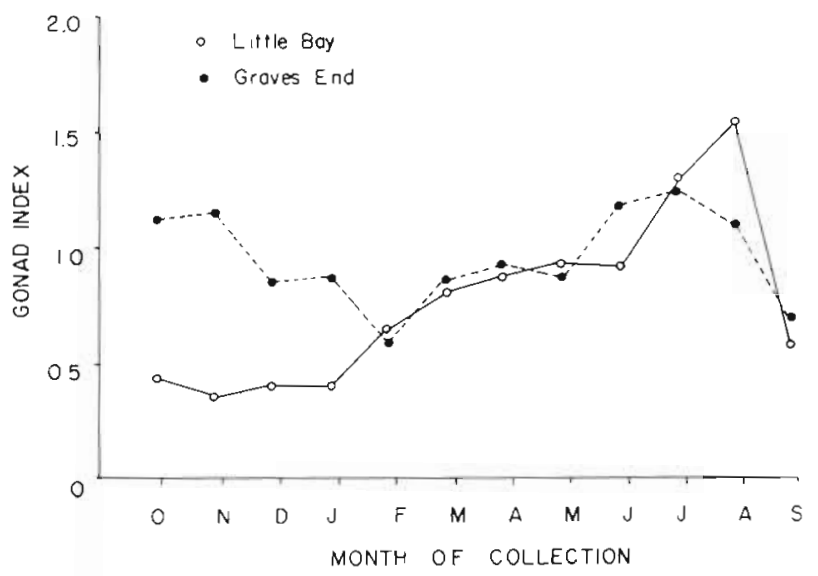

Fig. 2. Seasonal changes in gonad indices of Echinometra Iucunter from Little Bay and Graves End

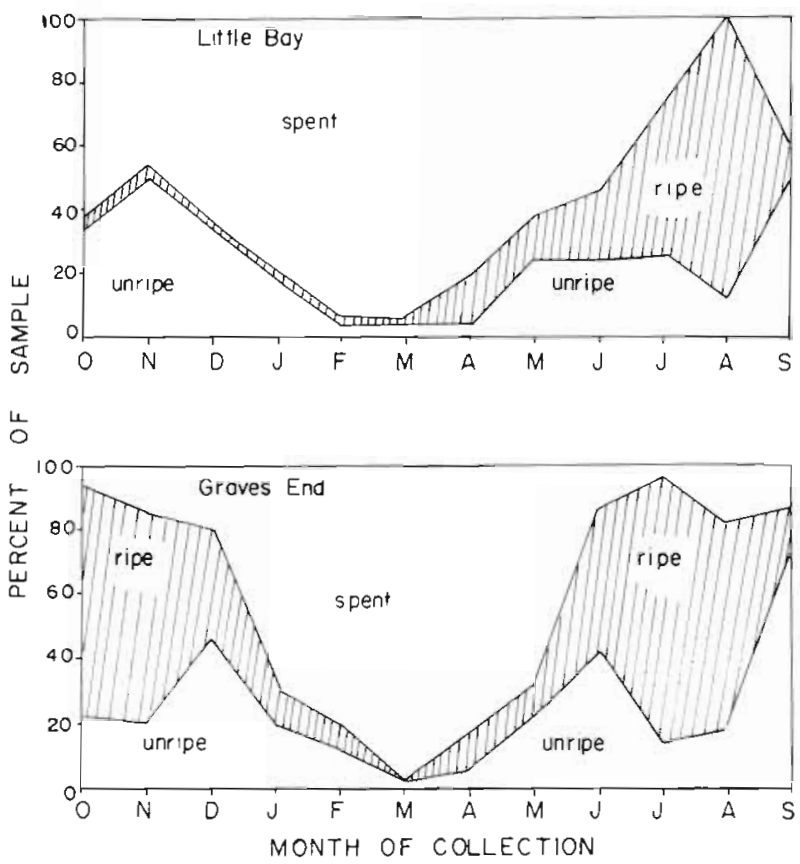

Fig. 3. Seasonal changes in gonad condition of Echinometra Iucunter from Little Bay and Graves End 
second peak in July. Thus, spawning occurred in November and again in July in the Graves End population.

The results of analyses of colour differences are presented in Table 1 . The colour differences were

Table 1. Echinometra Iucunter. Spine and test colouring of urchins in Little Bay and Graves End

\begin{tabular}{|c|c|c|c|c|c|}
\hline \multirow[t]{2}{*}{ Test colour } & \multicolumn{5}{|c|}{ Spine colour } \\
\hline & red & black & brown & green & Total \\
\hline \multicolumn{6}{|l|}{ Graves End } \\
\hline red & 124 & 123 & 388 & 178 & 813 \\
\hline black & 0 & 213 & 2 & 8 & 223 \\
\hline brown & 0 & 2 & 51 & 10 & 63 \\
\hline green & 0 & 0 & 4 & 13 & 17 \\
\hline Total & 124 & 338 & 445 & 209 & 1116 \\
\hline \multicolumn{2}{|c|}{ Degrees of freedom $=9$} & \multicolumn{2}{|c|}{$x^{2}=629.36$} & \multicolumn{2}{|c|}{$P<0.001$} \\
\hline \multicolumn{6}{|l|}{ Little Bay } \\
\hline red & 39 & 155 & 334 & 23 & 551 \\
\hline black & 0 & 523 & 2 & 2 & 527 \\
\hline brown & 0 & 2 & 23 & 1 & 26 \\
\hline green & 1 & 0 & 0 & 0 & 1 \\
\hline Total & 40 & 680 & 359 & 26 & 1105 \\
\hline \multicolumn{2}{|c|}{ Degrees of freedom $=9$} & \multicolumn{2}{|c|}{$X^{2}=618.73$} & \multicolumn{2}{|c|}{$P<0.001$} \\
\hline
\end{tabular}

significant at the $\mathrm{P}<0.001$ level (chi-square test). Most of the urchins from Little Bay have a black test and black spines or red test and brown spines. Those from Graves End tend to be more varied but the majority have red tests and brown spines. A considerable number have red tests and red or green spines.

There was a difference in mean spine length of urchins from the 2 habitats. Urchins of 26 to $45 \mathrm{~mm}$ test length from Little Bay had longer spines (mean $=61 \mathrm{~mm}, \mathrm{n}=85)(\mathrm{P}<0.05)$.

Analysis of covariance tests (Table 2) were used to compare the relationship of test thickness, test height, and test width to test length of urchins in the 2 populations. Tests showed that urchins from Graves End

Table 2. Echinometra lucunter. ANOCOV tables for (1) test thickness, (2) test height, and (3) test width to test length

\begin{tabular}{|lrrcc|}
\hline $\begin{array}{l}\text { Source of } \\
\text { variation }\end{array}$ & d.f. & $\begin{array}{c}\text { Mean } \\
\text { square }\end{array}$ & $\begin{array}{c}\text { F } \\
\text { Test }\end{array}$ & P \\
\hline $\begin{array}{l}\text { (1) Among means } \\
\text { within groups }\end{array}$ & 1 & 0.1574 & 21.31 & 0.01 \\
(2) Among means & 1 & 0.0074 & & \\
within groups & 201 & 0.0182 & 48.51 & 0.01 \\
(3) Among means & 1 & 1.5039 & 151.90 & 0.01 \\
within groups & 201 & 0.0099 & & \\
\hline
\end{tabular}

( $n=103$ ) were taller, wider and had thinner tests per unit length than those from Little Bay $(n=101)$. The mean test heights, widths and thickness of Graves End and Little Bay urchins were all significantly different at the 0.001 level of confidence.

Table 3 lists the kinds and number of oculars found insert in the examination of urchins from Little Bay and

Table 3. Echinometra lucunter. Patterns of ocular plate insertion in urchins from Little Bay and Graves End

\begin{tabular}{|lrrrrrr|}
\hline \multirow{2}{*}{ Area } & \multicolumn{5}{c|}{ Ocular plates inserted } \\
& $\mathrm{I}$ & $\mathrm{V}$ & $\mathrm{V}+\mathrm{I}$ & $\mathrm{IV}, \mathrm{V}+\mathrm{I}$ & None & Total \\
\hline Little Bay & 1 & 35 & 40 & 1 & 24 & 101 \\
Graves End & 1 & 55 & 3 & 0 & 43 & 102 \\
Total & 2 & 90 & 43 & 1 & 67 & 203 \\
\multicolumn{2}{l}{ Degrees of freedom $=4$} & $\mathrm{X}^{2}=44.8$ & $\mathrm{P}<0.001$ \\
\hline
\end{tabular}

Graves End. The pattern of ocular insertion was significantly different at the 0.001 level in the 2 populations studied. It was also highly variable among individuals of the same population. This is in contrast to the work of Mortenson (1943) who found that only ocular IV and sometimes ocular $\mathrm{V}$ were inserted in the periport in Echinometra lucunter.

The frequency distribution of mean numbers of pore pairs in the 2 groups of urchins is shown in Table 4.

Table 4. Echinometra lucunter. Frequency of occurrence of 4 pore-pair arc types in Little Bay and Graves End urchins

\begin{tabular}{|lccccc|}
\hline Area & $\begin{array}{c}\text { No. of } \\
\text { 5-pore } \\
\text { arcs }\end{array}$ & $\begin{array}{c}\text { No. of } \\
\text { 6-pore } \\
\text { arcs }\end{array}$ & $\begin{array}{c}\text { No. of } \\
7 \text {-pore } \\
\text { arcs }\end{array}$ & $\begin{array}{c}\text { No. of } \\
8 \text {-pore } \\
\text { arcs }\end{array}$ & Total \\
\hline Little Bay & 116 & 767 & 125 & 2 & 1010 \\
Graves End & 152 & 764 & 112 & 2 & 1030 \\
Total & 268 & 1531 & 237 & 4 & 2040 \\
Degrees of freedom $=3$ & $\mathrm{X}^{2}=5.60$ & $0.20>P>0.10$ \\
\hline
\end{tabular}

The differences in pore pair counts were not significantly different $(\mathrm{P}>0.10)$ and thus the 2 populations may be considered to be the same in this respect.

Thus, several morphological differences existed between urchins from Little Bay and Graves End. Urchins from Little Bay had thicker tests and were flatter and narrower per unit length than those from Graves End. Narrower and flatter tests would be an advantage in the Little Bay population by lessening the test resistance under conditions of heavy wave action. Thicker tests in the same population would 
increase structural strength. Moore (1935) also reported that Echinus esculentus from a 'breakwater' habitat was both flatter and thicker-shelled than populations from two sheltered areas.

Urchins from Little Bay also had significantly longer spines per unit test length than those from Greaves End. One might expect that urchins from Little Bay would have shorter spines due to abrasion caused by heavy wave action. On the other hand, there was no loose rubble rock at Little Bay to erode the spines. The urchins of Graves End live under and in the crevices of unstable rubble rocks and spines may be worn down by intermittent movement.

Test and spine colour were significantly different at the 2 sites with the colour being more variable at Graves End. This was likely due to differences in food sources, for urchins at Little Bay scrape blue-green and coralline algae from the substrate in the absence of macophytes (McLean, 1964, 1967), while the urchins at Graves End have a broader range of algal food available.

Finally, there was a difference in the pattern of insertion of oculars in the 2 populations. At Little Bay, oculars $\mathrm{V}$ or none, or $\mathrm{V}+1$ were insert, while at Graves End urchins had all oculars, were excert or only ocular V insert. Although Hyman (1955) has noted that the pattern of ocular arrangement was variable within echinoid populations and varied with size, Swan (1966) suggested that numbers and arrangement of ocular plates may be due to selective variation. The differences in ocular insertion between Little Bay and Graves End urchins may also be due to constraints of differences in shape of the tests between the 2 populations.

There were also marked differences between the populations in 2 life history traits - size and reproductive cycle. Urchins from Graves End attain a larger size than do those from Little Bay. The monthly mean test lengths of Graves End urchins were significantly higher (in 10 or 12 collections) than the mean test length of Little Bay urchins. The smaller size of the Little Bay urchins may be due to less food availability or, as Lawrence and Kafri (1979) have suggested, to increased mortality in a high wave-energy habitat. The greater densities of urchins from protected habitats (Lawrence and Kafri, 1979) support the latter view.

The population of urchins at Little Bay spawned only once a year with gametes released in July and August. At Graves End the urchins also spawned in July and August, but a second release of gametes was apparent during the previous October and November. It is arguable that environmental stress (wave action) at Little Bay limited the breeding activity of urchins while a more benign environment at Graves End allowed two peaks of spawning to develop. The length and timing of breeding cycles in echinoids is highly variable annually and geographically, but most species exhibit a single annual cycle (Boolootian, 1966). McPherson (1969) found that Echinometra lucunter from different habitats in Florida had similar reproductive cycles although relative growth of gonads differed. On the other hand, Pearse (1969) found well-defined reproductive periodicities in $E$. mathaei (de Blainville) near the head of the Gulf of Suez, while further south near the mouth and in the Red Sea there was no synchronized periodicity. Two peaks of spawning of urchins at Graves End are thus an unusual life history trait. However, it should be noted that data on reproduction was obtained for a single year only and this does not justify the assumption that the 2 peaks of spawning at Graves End occur every year.

Acknowiedgement. This work was supported by a grant in aid of research from the Natural Sciences and Engineering Research Council of Canada.

\section{LITERATURE CITED}

Abbott, D. P., Ogden, J. C., Abbott, I. A. (1974). Studies on the activity pattern, behavior and food of the echinoid Echinometra lucunter (Linnaeus) on beachrock and algal reefs at St. Croix, U. S. Virgin Islands. Spec. Publ. No. 4 West Indies Lab. Fairleigh Dickinson Univ., St. Croix, U. S. Virgin Islands, p. 1-111

Boolootian, R. A. (1966). Reproductive physiology. In: Boolootian, R. A. (ed.) Physiology of Echinodermata. Interscience Publishers, New York, London, p. 561-613

Clark, H. L. (1919). The distribution of the littoral echinoderms of the West Indies. Carnegie Inst. Wash. Tortugas Lab. Papers 13: 51-73

Clark, H. I. (1921). Report on the Echinoidea collected by the Barbados-Antigua Expedition. Univ. Iowa Studies Nat. Hist. 9: 103-121

Doderlein, L., Hartmeyer, R. (1916). Westindische Seeigel und Seesterne. Ergebnisse einer zoologischen Forschungsreise nach Westindien von W Kukenthal und R. Hartmeyerin. Zool. Jb. 11 (Suppl.)

Harding, J. P. (1949). The use of probability paper for the graphical analysis of polymodial frequency distributions. J. mar. biol. Ass. U. K. 28: 141-153

Hyman, L. H. (1955). The invertebrates, Vol. 4, Echinodermata. McGraw-Hill, New York

Kier, P. M., Grant, R. E. (1965). Echinoid distribution and habits, Key Largo Coral Reef Preserve, Florida. Smithson. misc. Collns 149: 1-68

Koehler, A. (1908). Asteries, Ophiures et Echinides de l'Exped. Antaret Ecossaise 'Scotia'. Trans. R. Soc. Edinburgh XLVI: 1-640

Lawrence, J. M., Kafri, J. (1979). Numbers, biomass and caloric content of the Echinoderm fauna of the rocky shores of Barbados. Mar. Biol. 52: 87-91

Lewis, J. B. (1960). The fauna of rocky shores of Barbados, West Indies. Can. J. Zool. 38: 391-435

Lovén, S. (1874). Etudes sur les Echinoidees. K. svenska Vetensk Akad. Handl., N. S. $11(7): 91$ pp +53 plates 
Mayr, E. (1954). Geographic speciation in tropical echinoids Evolution 8: 1-18

McLean, R. F. (1964). Mechanical and biological erosion of beachrock in Barbados, West Indies. Ph. D. thesis, Geography Department, McGill University, Montreal, Canada

McLean, R. F. (1967). Erosion of burrows in beachrock by the tropical sea urchin, Echinometra lucunter. Can. J. Zool. 45: $586-588$

McPherson, B. F. (1969). Studies on the biology of the tropical sea urchins, Echinometra lucunter and Echinometra viridis. Bull. mar. Sci. 19: 194-213

Moore, H. B. (1934). A comparison of the biology of Echinus esculentus in different habitats, Part I. J. mar. biol. Ass. U. K. 19: 869-885

Moore, H. B. (1935). A comparison of the biology of Echinus esculentus in different habitats, Part II. J. mar. biol. Ass U. K. 20: 109-128

Mortensen, T. (1943). A monograph of the Echinoidea. III, 3. Camarodonta. II, Echinidae, Strongylocentrotidae, Paraseleniidae, Echinometridae. C. A. Reitzel, Copenhagen, $446+23$ pp, 66 pls.

Pearse, J. S. (1969). Reproduction periodicities of Indo-Pacific invertebrates in the Gulf of Suez. II. The echinoid Echinometra mathaei (de Blainville). Bull. mar. Sci. 19: 580-613

Swan, E. F. (1966). Growth, autotomy and regeneration. In: Boolootian, R. A. (ed.) Physiology of Echinodermata. Interscience Publishers, New York, London, p. 153-434

Accepted for printing on August 3, 1983 